\title{
A Research for special piers' adjustment of steel pipe pile position: A case of Penang second marine bridge
}

\author{
Kang Huang ${ }^{1, a}$ \\ ${ }^{1}$ No.85 Deshengmenwai Street,Xicheng District,Beijing,China \\ ahuangkang99@163.com
}

\section{Keywords: Steel Pipe Pile, Position Adjustment, Comparison Differences}

Abstract. The aim of this preliminary research is to study the precision of pile foundation position compared to its original designed location. Before the installation of steel pipe piles for this project, the subcontractor found that the present vessel and equipment could not fully satisfy the plan twist angle and inclination requirements as shown on the detailed design drawings. Adjustment to the twist angle was needed for individual piles in some pier locations. In connection to the pile positions after the adjustment, this research has compared the pile forced loads with that of the original layout, and found that the structural impact is very insignificant due to the change in twist angle. It is confirmed that the revised pile group layout is acceptable. The relevant detail design is still applicable and amendment is unnecessary. The recommendation of this research could be adopted for the similar huge marine structures which installed large diameter steel pipe piles.

\section{Introduction}

The Penang Second marine bridge project is approximately $22 \mathrm{~km}$ in length with a total of 16.5 kilometres of bridgeworks of which around $15 \mathrm{~km}$ is over water. The bridge is made up of multiple approach span viaducts from both sides with a signature structure featuring longer spans and a higher clearance envelope over the southern navigation channel. The general view of the bridge is shown in figure 1.The high piers close to the cable-stayed bridge for the viaduct consist of a reinforced concrete pier head on raked steel pipe pile foundations. The cross section of typical pier with the steel pipe pile's foundation is shown in figure 2.

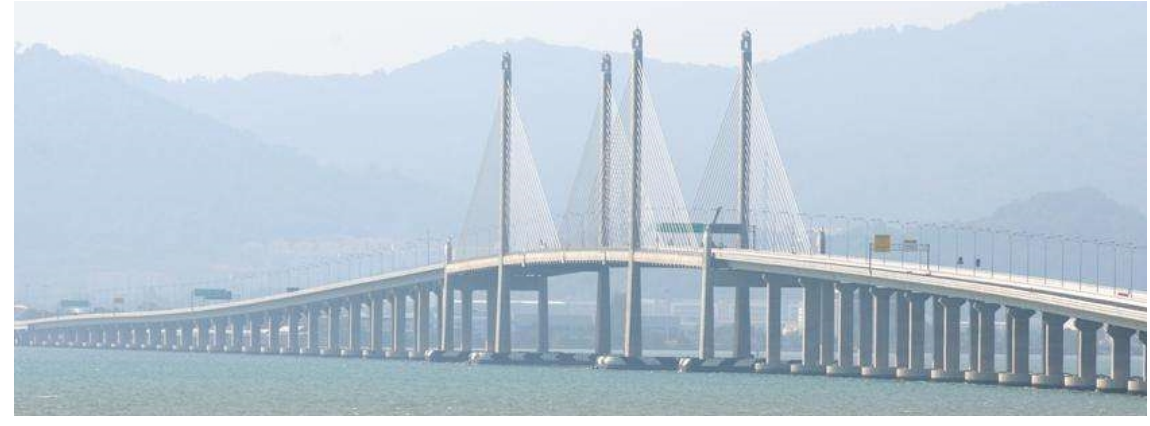

Fig.1 General view of Penang Second Marine Bridge.

Before the installation of steel pipe piles for this project, the subcontractor found that the present vessel and equipment could not fully satisfy the plan twist angle and inclination requirements as shown on the detailed design drawings. The similar conditions often occur in large diameter piles construction[1]. Therefore, adjustment to the twist angle is needed for individual piles in some pier locations. The angle of twist on plan and inclination are needed to adjust at specific piles in the following pier positions. The reason is mainly to facilitate vessel and machinery for the pile driving. The specific pier positions and the reasons of adjustment are listed in the below table1. The deviation restriction discription could be found in the relevant British standard [2] and Hong Kong Practice[3]. 


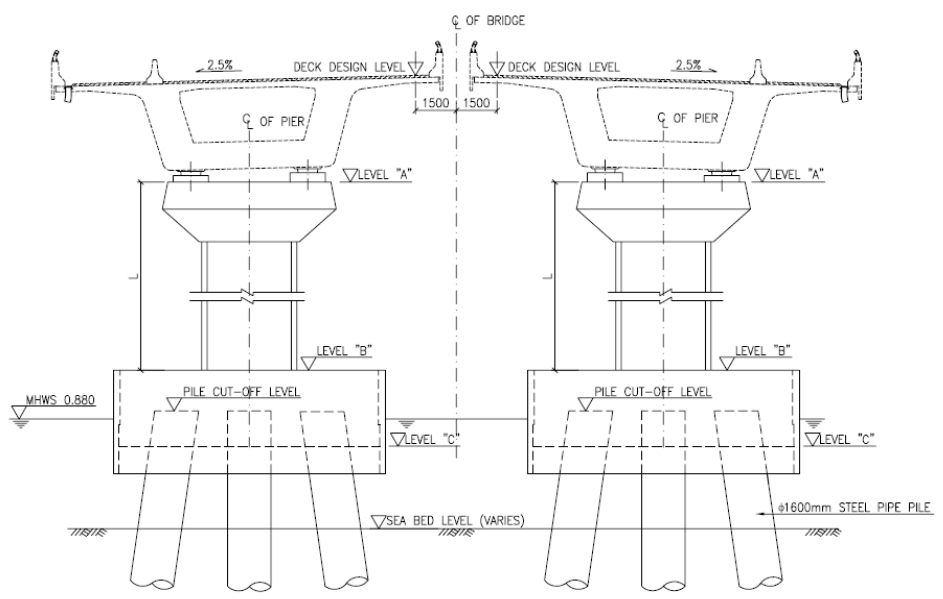

Fig.2 Typical pier, elevation and cross section

Table 1 Location and Reason of the Adjustment

\begin{tabular}{|c|c|l|l|}
\hline $\begin{array}{c}\text { Pilecap } \\
\text { Type }\end{array}$ & $\begin{array}{c}\text { No. of Piles } \\
\text { Adjusted in } \\
\text { per Pilecap }\end{array}$ & \multicolumn{1}{|c|}{$\begin{array}{c}\text { Description to the } \\
\text { Adjustment }\end{array}$} & \multicolumn{1}{c|}{$\begin{array}{c}\text { Reasons of } \\
\text { Adjustment }\end{array}$} \\
\hline Type1 & 1 Nos & $\begin{array}{l}\text { Adjustment is } \\
\text { proposed to the plan } \\
\text { twist angle for one pile } \\
\text { only. }\end{array}$ & $\begin{array}{l}\text { The present piling vessel and } \\
\text { equipment cannot fully satisfy } \\
\text { the pile positions as indicated on } \\
\text { the original detailed design } \\
\text { drawings. Therefore, minor } \\
\text { adjustment to the plan twist } \\
\text { angle is required to specific } \\
\text { piles. }\end{array}$ \\
\hline Type2 & 1 Nos & $\begin{array}{l}\text { Adjustment is } \\
\text { proposed to the plan } \\
\text { twist angles in two } \\
\text { piles. }\end{array}$ \\
\hline
\end{tabular}

The changes in twist angle are shown in the below table 2. From the above comparison, it is found that only minor adjustment to the twist angles in individual piles and the adjustment is very minor.

Table 2 Details of the Adjustment for per Type

\begin{tabular}{|c|c|c|c|c|}
\hline $\begin{array}{c}\text { Pilecap } \\
\text { Type }\end{array}$ & $\begin{array}{l}\text { Left Pile Cap } \\
\text { (Shaded represents pile to } \\
\text { be adjusted.) }\end{array}$ & $\begin{array}{l}\text { Right Pile Cap } \\
\text { (Shaded represents pile to } \\
\text { be adjusted.) }\end{array}$ & $\begin{array}{l}\text { Original Twist } \\
\text { Angle }\end{array}$ & $\begin{array}{l}\text { Present } \\
\text { Twist } \\
\text { Angle }\end{array}$ \\
\hline Type 1 & & & $\begin{array}{l}\# 07-80^{\circ} \\
\# 09-80^{\circ}\end{array}$ & $\begin{array}{l}\# 07-55^{\circ} \\
\# 09-55^{\circ}\end{array}$ \\
\hline $\begin{array}{l}\text { Type } 2 \\
\text { (except } \\
\text { for }\end{array}$ & & & $\begin{array}{l}\# 07-80^{\circ} \\
\# 08-80^{\circ}\end{array}$ & $\begin{array}{l}\# 07-55^{\circ} \\
\# 08-55^{\circ}\end{array}$ \\
\hline P32) & & & & \\
\hline
\end{tabular}




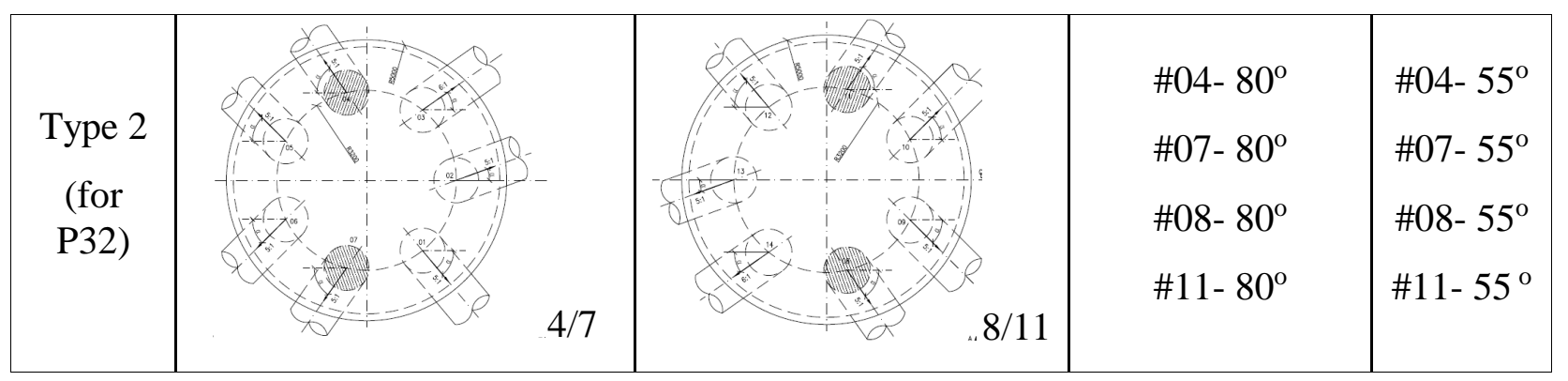

\section{Piling Research}

\section{Research Principle}

The widely adopted pile soil interaction model in the engineering field in the world is Winkler medium modulus of subgrade reaction method. The description of details can refer to the classic textbook[4].

For analysing computer model, The global analysis software for approach bridge is adopted. After loading to the structural component in soil, there would be displacement and subsequently soil compression. Meanwhile, the soil would produce resistance to the structural component. If it is to regard the soil as an elastic deformation medium, with the introduction of the E. Winkler assumption, it is assumed that soil resistance is directly proportional to the soil compression, and this resistance is called as "soil elastic resistance".

For pile inside soil with horizontal displacement, the horizontal soil resistance force Sx. According to the above assumption, the horizontal soil resistance can be expressed as:

$$
\text { Sx }=\text { Cy X }
$$

$\mathrm{Sx}=$ horizontal soil resistance force in unit area $[\mathrm{kPa}]$

$\mathrm{X}=$ the horizontal displacement in certain point of the pile[m]

$\mathrm{Cy}=$ pile horizontal soil subgrade coefficient $[\mathrm{kPa} / \mathrm{m}]$

For real and quick comparison of the difference between old and new pile group arrangements, based on the premise that linear superposition can be adopted in design parameters and calculation principles and the change in pile position very small (basically the adjustment in twist angle), we can use the same external loading applied on both new and old pile group layout for the three pile cap types and calculate the difference in pile loads in respective pile groups. By comparison to the calculation results, the effect due to adjustment in pile position can be obtained.

If the difference is small (within the $\pm 5 \%$ ), it can be concluded that the new pile group arrangement will have negligible structural effect and can be ignored. However, if the result shows substantial difference, new calculation shall be conducted according to the actual loading conditions.

\section{Research Parameter}

The research of calculation consists of the steel pipe pile, soil condition and impact loading. The details of Steel Pipe Pile's elements are listed in below table3.The details of Soil condition are shown in below table4.

The pile loads can be calculated for both the new and old pile group layouts. By comparison to the calculation results, the degree of changes in pile loads can be obtained. From the relevant design parameters and theory for calculation, they are in the linear relationship. For simplifying calculation loadings, Assuming the same external loadings is available. The assumed Loading for Comparison is listed in table5.Therefore, through the degree of changes in the pile loadings and the integration with original detail design, it can be concluded that the piles can satisfy the structural requirement. In the comparison of the pile load changes, the following three loading (at the bottom of Pilecap) conditions are considered to cover the loading pattern at the underside of pile cap. 
Table 3 Details of the Steel Pipe Pile

\begin{tabular}{|l|c|l|}
\hline Ground level before scour & $-8.1 \sim-9.5$ & {$[\mathrm{~m}]$} \\
\hline Local scour depth & About 4.2 & {$[\mathrm{m}]$} \\
\hline Ground level at piers after scour & $-12.3 \sim-13.7$ & {$[\mathrm{~m}]$} \\
\hline Pile shape & Hollow pile & - \\
\hline Material & Steel S355J0 & - \\
\hline Elastic Modulus & $2.1 \mathrm{E}+08$ & {$\left[\mathrm{kN} / \mathrm{m}^{2}\right]$} \\
\hline Poisson's ratio & 0.3 & - \\
\hline Density & 77 & {$\left[\mathrm{kN} / \mathrm{m}^{3}\right]$} \\
\hline calculated thickness & 19.0 & {$[\mathrm{~mm}]$} \\
\hline Piles pinned (0) or fixed (1) to pile cap & 1 & - \\
\hline
\end{tabular}

Table 4 Details of the Soil condition

\begin{tabular}{|l|l|c|}
\hline Axial: Surface shear modulus, $\mathrm{G}_{0}$ & 0 & {$\left[\mathrm{kN} / \mathrm{m}^{4}\right]$} \\
\hline Axial: Shear modulus gradient, $\mathrm{dG} / \mathrm{dz}$ & 3000 & {$\left[\mathrm{kN} / \mathrm{m}^{4}\right]$} \\
\hline Axial: Shear modulus below base, $\mathrm{G}_{\mathrm{b}}$ & $\mathrm{Go}+\mathrm{G}_{\mathrm{m}} \mathrm{L}$ & {$\left[\mathrm{kN} / \mathrm{m}^{4}\right]$} \\
\hline Lateral: Surface shear modulus, $\mathrm{G}(0)$ & 0 & {$\left[\mathrm{kN} / \mathrm{m}^{4}\right]$} \\
\hline Lateral: Shear modulus gradient, $\mathrm{dG} / \mathrm{dz}$ & 3000 & {$\left[\mathrm{kN} / \mathrm{m}^{4}\right]$} \\
\hline Poisson's ratio (all loading modes) & 0.25 & - \\
\hline
\end{tabular}

Table 5 Assumed Loading for Comparison

\begin{tabular}{|c|c|c|c|c|c|}
\hline \multirow{2}{*}{ Case } & $\begin{array}{c}\text { Vert. } \\
\text { Load }\end{array}$ & $\begin{array}{c}\text { Longitudinal } \\
\text { load, Fl }\end{array}$ & $\begin{array}{c}\text { Transverse } \\
\text { losf, Ft }\end{array}$ & $\begin{array}{c}\text { Longitudinal } \\
\text { Moment,Ml }\end{array}$ & $\begin{array}{c}\text { Transverse } \\
\text { Moment, Mt }\end{array}$ \\
\cline { 2 - 6 } & {$[\mathrm{kN}]$} & {$[\mathrm{kN}]$} & {$[\mathrm{kN}]$} & {$[\mathrm{kN} . \mathrm{m}]$} & {$[\mathrm{kN.m}]$} \\
\hline 1 & 2000 & 100 & - & 1000 & - \\
\hline 2 & 2000 & - & 100 & - & 1000 \\
\hline 3 & 2000 & 100 & 100 & 1000 & 1000 \\
\hline
\end{tabular}

\section{Research modeling}

According to the above calculation assumption and principles, the three dimensional bridge software was adopted and analysis models with local adjustment to the individual piles were established for the three types of pile caps Type 1, Type 2 (except for P32) and Type 2 (P32). The below Figure3 listes the specific analysis modeling for the representative Type 1 and Type 2 (except for P32).

\begin{tabular}{|c|c|}
\hline $\begin{array}{c}\text { TYPE1 (Model only shown half of } \\
\text { the pilecap) }\end{array}$ & $\begin{array}{c}\text { TYPE2 (Model for P32 is similar and } \\
\text { not shown) }\end{array}$ \\
\hline
\end{tabular}

Fig.3 Structural Modeling of Analysis 


\section{Result Comparison and Assessment}

According to the calculation, the maximum pile loads at the top portion of the piles are listed for the three different pile cap types. The results of TYPE1,TYPE2(Except for P32) and TYPE2 (P32) are shown in below table 6, table 7and table 8 .

Table 6 Details of TYPE1 Result

Unit:[kN,m]

\begin{tabular}{|c|r|r|r|r|r|r|r|r|r|}
\hline \multirow{2}{*}{$\begin{array}{c}\text { Pile } \\
\text { No }\end{array}$} & \multicolumn{4}{|c|}{ Old Arrangement } & \multicolumn{3}{c|}{ New Arrangement } & \multicolumn{3}{c|}{ Comparison Differences } \\
\cline { 2 - 10 } & $\begin{array}{c}\text { Vert. } \\
\text { N1 }\end{array}$ & $\begin{array}{c}\text { Shear } \\
\text { S1 }\end{array}$ & $\begin{array}{c}\text { Bending } \\
\text { M1 }\end{array}$ & $\begin{array}{c}\text { Vert. } \\
\text { N2 }\end{array}$ & $\begin{array}{c}\text { Shear } \\
\text { S2 }\end{array}$ & $\begin{array}{c}\text { Bending } \\
\text { M2 }\end{array}$ & $\begin{array}{c}\text { (N2-N1) } \\
\text { / N1 }\end{array}$ & $\begin{array}{c}\text { (S2-S1) } \\
\text { / S1 }\end{array}$ & $\begin{array}{c}\text { (M2-M1) } \\
\text { / M1 }\end{array}$ \\
\hline Max & 192 & 20 & 98 & 189 & 20 & 96 & -0.02 & -0.01 & -0.02 \\
\hline Min & 64 & 1 & 5 & 59 & 1 & 2 & 0.00 & 0.00 & 0.00 \\
\hline
\end{tabular}

Table 7 Details of TYPE2(Except for P32) Result Unit:[kN,m]

\begin{tabular}{|c|c|c|c|c|c|c|c|c|c|}
\hline \multirow{2}{*}{$\begin{array}{c}\text { Pile } \\
\text { No }\end{array}$} & \multicolumn{4}{|c|}{ Old Arrangement } & \multicolumn{3}{c|}{ New Arrangement } & \multicolumn{3}{c|}{ Comparison Differences } \\
\cline { 2 - 10 } & $\begin{array}{c}\text { Vert. } \\
\text { N1 }\end{array}$ & $\begin{array}{c}\text { Shear } \\
\text { S1 }\end{array}$ & $\begin{array}{c}\text { Bending } \\
\text { M1 }\end{array}$ & $\begin{array}{c}\text { Vert. } \\
\text { N2 }\end{array}$ & $\begin{array}{c}\text { Shear } \\
\text { S2 }\end{array}$ & $\begin{array}{c}\text { Bending } \\
\text { M2 }\end{array}$ & $\begin{array}{c}\text { (N2-N1) } \\
\text { / N1 }\end{array}$ & $\begin{array}{c}\text { (S2-S1) } \\
\text { / S1 }\end{array}$ & $\begin{array}{c}\text { (M2-M1) } \\
\text { / M1 }\end{array}$ \\
\hline Max & 413 & 19 & 85 & 416 & 19 & 73 & 0.01 & -0.04 & -0.14 \\
\hline Min & 163 & 10 & 24 & 163 & 11 & 28 & 0.00 & 0.09 & 0.18 \\
\hline
\end{tabular}

Table 8 Details of TYPE2(P32) Result Unit:[kN,m]

\begin{tabular}{|c|c|c|c|r|r|r|r|r|r|}
\hline \multirow{2}{*}{$\begin{array}{c}\text { Pile } \\
\text { No }\end{array}$} & \multicolumn{4}{|c|}{ Old Arrangement } & \multicolumn{3}{c|}{ New Arrangement } & \multicolumn{3}{c|}{ Comparison Differences } \\
\cline { 2 - 10 } & $\begin{array}{c}\text { Vert. } \\
\text { N1 }\end{array}$ & $\begin{array}{c}\text { Shear } \\
\text { S1 }\end{array}$ & $\begin{array}{c}\text { Bending } \\
\text { M1 }\end{array}$ & $\begin{array}{c}\text { Vert. } \\
\text { N2 }\end{array}$ & $\begin{array}{c}\text { Shear } \\
\text { S2 }\end{array}$ & $\begin{array}{c}\text { Bending } \\
\text { M2 }\end{array}$ & $\begin{array}{c}\text { (N2-N1) } \\
\text { / N1 }\end{array}$ & $\begin{array}{c}\text { (S2-S1) } \\
\text { / S1 }\end{array}$ & $\begin{array}{c}\text { (M2-M1) } \\
\text { / M1 }\end{array}$ \\
\hline Max & 413 & 19 & 85 & 443 & 21 & 90 & 0.07 & 0.09 & 0.06 \\
\hline Min & 163 & 10 & 24 & 143 & 8 & 11 & -0.12 & -0.19 & -0.53 \\
\hline
\end{tabular}

The calculation results in Tab 6 8 are summarized in Table 9. The degree of changes in each item of the forces are also listed. The relevant results are combining with the original design calculations.

Table 9 Assessment of the Each Type's Adjustment

\begin{tabular}{|c|c|c|c|l|}
\hline $\begin{array}{c}\text { Pliecap } \\
\text { Type }\end{array}$ & $\begin{array}{c}\text { MaxAxial } \\
\text { Force-Degree } \\
\text { of Change }\end{array}$ & $\begin{array}{c}\text { Max Shear } \\
\text { Force-Degree } \\
\text { of Change }\end{array}$ & $\begin{array}{c}\text { Max Bending } \\
\text { Moment-Degree } \\
\text { of Change }\end{array}$ & $\begin{array}{l}\text { Assessment to the Effect to } \\
\text { the Original Structure }\end{array}$ \\
\hline $\begin{array}{c}\text { Type1 } \\
\text { (Except for } \\
\text { P32) }\end{array}$ & $\uparrow 2 \%$ & $\downarrow 1 \%$ & $\downarrow 2 \%$ & $\begin{array}{l}\text { The result indicates that the } \\
\text { changes in forces on the } \\
\text { piles are very small. } \\
\text { That is the revised pile } \\
\text { group layout has negligible } \\
\text { structural impact and the } \\
\text { effect can be ignored. }\end{array}$ \\
\hline $\begin{array}{l}\text { Type2 } \\
\text { (P32) }\end{array}$ & $\uparrow 7 \%$ & $\downarrow 14 \%$ & $\begin{array}{l}\text { The working load at pile top } \\
\text { will increase slightly, the } \\
\text { increment is only around } \\
\text { 400kN; } \\
\text { The original proposed pile } \\
\text { length can satisfy the } \\
\text { geotechnical requirement; } \\
\text { The shear force and } \\
\text { bending moment on the pile } \\
\text { shaft are also increase } \\
\text { sightly. } \\
\text { As there is concrete plug at } \\
\text { the top portion of pile, the } \\
\text { flexural and shear } \\
\text { resistance can withstand the } \\
\text { increment in forces. }\end{array}$ \\
\hline
\end{tabular}

Note: $\downarrow$-Decrease; $\uparrow-$ Increase, 


\section{Pilecap Research}

From the calculation results indicated in Table 9, the adjusted pile groups in pile cap Type 1 and Type 2 have negligible impact to the pile forces and the structurak effect on pile shaft can therefore be ignored. Moreover, there is not any increase in the single pile reaction and hence new pile cap design calculation is not necessary.

The calculation reveals that the single pile reaction will increase about $7 \%$ due to the adjusted pile group layout. Conservatively, the single pile reactions located outside the critical section for bending moment checking are increased by $10 \%$ in the calculation. After conducting the calculation and checking, it is found that the pile cap is still astructurally adequate.

\section{Conclusion}

By integrating the above mentioned changes in pile group layout and the corresponding design calculation, it is revealed that:

For the pile group layouts in Type 1 and Type 2 (except for P32), as there is only the change in twist angle in a single pile, the impact to the pile group is very small and can be ignored.

For the pile group layout in Type 2 (P32), as the twist angles for two piles are changed, the impact to the pile group is the slight increase of load about $400 \mathrm{kN}$ in a single pile. There is not much difference in the bending moment and shear force in the pile shaft.

Through the above calculation for the adjusted pile group layout, it is found that the original design pile lengths, pile cap structural details and reinforcement designs are still applicable. The recommendation of this research could be adopted for the similar huge marine structures which installed large diameter steel pipe piles.

\section{References}

[1] Budi, Gogot Setyo, Charles, Wijaya,Hendry Christianto:Deviation of Position of Piles Foundation from Its Original Designed Location. Proceedings 10th Indonesian Geotechnical Engineering Conference and 19th Annual Scientific Meeting,Jakarta Indoensia (2015),p.469-474

[2] BS 8004:Code of Practice for Foundations, British Standard Institution, London (1986),p.122

[3] Geotechnical Engineering Office: FOUNDATION DESIGN AND CONSTRUCTION publication No. 1/2006, Geotechnical Engineering Office of Civil Engineering and Development Department, Hong Kong SAR Government (2006).p.166

[4] Tomlinson, M.J: Pile Design and Construction Practice,7th Edition, A Viewpoint Publication, Longman Publisher (2000),p.113 